\title{
Relation between chloride secretion and intracellular cyclic adenosine monophosphate in a cloned human intestinal cell line HT-29 cl 19A
}

\author{
S K Nath, X Huang, A L'helgoualc'h, M Rautureau, A Bisalli, M Heyman, J F Desjeux
}

\begin{abstract}
The relation between the intracellular cyclic adenosine monophosphate (cAMP) content and the electrogenic chloride secretion induced by cholera toxin was studied in secretory HT-29 $\mathrm{cl} 19 \mathrm{~A}$ cell monolayers. Cells were treated by the mucosal addition of cholera toxin $(5 \mu \mathrm{g} / \mathrm{ml})$ for 10,45 , or 90 minutes in Ussing chambers. After 10 minutes, the mean (SEM) intracellular cAMP content $(3 \cdot 2(0 \cdot 2)$ $\mathrm{pmol} / \mathrm{mg}$ protein) and short circuit current (Isc) $\left(1.9(0.3) \mu\right.$ A. $\left.\mathrm{cm}^{-2}\right)$ did not differ significantly from the corresponding basal values. At 45 minutes, a significant increase in the Isc (22.2 $\left.(5 \cdot 7) \mu \mathrm{A} \cdot \mathrm{cm}^{-2}\right)$ was accompanied by a significant elevation in cAMP $(10(1.7) \mathrm{pmol} / \mathrm{mgh}$ protein $)$. At 90 minutes, when the stimulated Isc plateaued $\left(35.2(5 \cdot 2) \mu \mathrm{A} . \mathrm{cm}^{-2}\right)$, the cAMP value $(99.2(23.8) \mathrm{pmol} / \mathrm{mg}$ protein) increased further. The protein kinase C (PKC) activity of the cells was not affected by cholera toxin. Treatment of cell monolayers by different concentrations of DbcAMP $\left(10^{5}, 5 \times 10^{-5}, 10^{-3} \mathrm{M}\right)$ showed that the minimal concentration of DbcAMP (serosal) which significantly increased the Isc $\left(\Delta 4.5 \mu \mathrm{A} . \mathrm{cm}^{-2}\right)$ was $10^{-4} \mathrm{M}$, and that this was accompanied by an increase in cAMP of $\Delta 6.7 \mathrm{pmol} / \mathrm{mg}$ protein: Compared with DbcAMP, cholera toxin stimulated the Isc (at 45 minutes) to a much higher degree with a comparable elevation of cAMP. It is concluded that in cl 19A cells there is a threshold value of increase in intracellular cAMP that induces chloride secretion. Cholera toxin stimulated chloride secretion can be explained predominantly by an increase in intracellular cAMP that is unrelated to PKC activity.
\end{abstract}

(Gut 1994; 35: 631-636)

Cholera causes serious diarrhoea that often leads to severe dehydration. The mechanism involved in the pathogenesis of this life threatening diarrhoea is complex. The oligomeric peptide enterotoxin produced by Vibrium cholerae is mainly responsible for the secretory diarrhoea. Recently, some strains of $V$ chloreae were shown to produce additional toxins such as zonula occludens toxin (ZOT) and the accessory cholera enterotoxin (ACE). ${ }^{1}$ The action of cholera toxin on intestinal secretion is principally mediated through the activation of adenylate cyclase subsequent to the fixation of the toxin on the cells lining the intestinal epithelium. ${ }^{2-4}$

In addition to its direct action on the cells, cholera toxin influences intestinal secretion indirectly through the enteric nervous system. Studies using blockers of the neuronal synaptic transmission or neuromediators have shown that indirect stimulation may contribute up to $80 \%$ of the total secretory response elicited by cholera toxin. ${ }^{5-8}$ Ionic flux studies showed that blocking neuronal transmission actually abolishes the reduced electroneutral $\mathrm{NaCl}$ absorption that accompanies cholera. ${ }^{9}$ The site of $\mathrm{NaCl}$ absorption is the villi. These findings seriously question the actual role played by cyclic adenosine monophosphate (cAMP) as the intracellular messenger in cholera toxin-induced diarrhoea and the contribution of electrogenic chloride secretion in the severe diarrhoea that accompanies cholera. We therefore aimed to study whether cholera toxin induces chloride secretion by acting directly on the secretory cells to increase intracellular cAMP and whether increased cAMP accounts for this event.

To test this hypothesis three points had to be addressed. Firstly, we had to have a model of chloride secretory cells devoid of the underlying tissues and hence free from the influence of the enteric nervous system. Secondly, the concentration of cAMP and chloride secretion in the same cell monolayers had to be measured. Thirdly, we needed to establish a time relationship between the increase in cAMP and chloride secretion.

This study is part of a general study to assess the role of chloride secretory intestinal epithelial cells in cholera.$^{10}$ Monoloyers of a cloned human colonic carcinoma cell line that secretes chloride, HT29 cl 19A, were used. The advantage of this approach is that the epithelial layer is free of the underlying tissue. Moreover, by using permanent cell lines we are, in principle, dealing with the same tissue throughout the series of experiments. However, with the cell lines studied previously ${ }^{11}$ there were some difficulties in obtaining monolayers with standardised basal electrical parameters because the cell lines were not cloned and the culture conditions, including the type of support to obtain the monolayers, were not thoroughly standardised. Of possible factors in addition to cAMP, protein kinase $\mathrm{C}$ (PKC) has been shown to have a role in the regulation of epithelial chloride transport. More interestingly, PKC either inhibits or potentiates cAMP production in some cell types. We, therefore, also studied if cholera toxin has any effect on PKC activity of the epithelial cells. This study aimed to optimise cell culture conditions in order to obtain cl 19A monolayers with standardised electrical parameters. Subsequently, the time course of action of cholera toxin on electrogenic chloride secretion and its relation to intracellular cAMP and PKC activity were investigated to determine the direct mechanism by 
which cholera toxin stimulates cellular electrogenic chloride secretion.

\section{Methods}

CELL CULTURE

The cl 19A cell line is a differentiated clone of the human colonic adenocarcinoma cell line HT-29.2 and was obtained from Dr Laboisse (INSERM U.239, Paris, France). Freshly trypsinised cells were grown in Dulbecco's modified Eagle's minimum essential medium (Boehringer Mannheim, Germany) supplemented with $10 \%$ fetal bovine serum (Boehringer Mannheim, Germany) and 4 $\mathrm{mmol} / \mathrm{ml}$ glutamine (GIBCO, Paisley, Scotland) at $37^{\circ} \mathrm{C}$ in a humidified $6 \% \mathrm{CO}_{2}, 94 \%$ room air atmosphere.

The cells were routinely screened for mycoplasma contamination using Chen's method,,$^{13}$ and they were always found to be free of this. Confluent monolayers were subcultured every seventh day in $25 \mathrm{~cm}^{2}$ plastic flasks. The medium was changed daily. Cells were grown on Transwell porous-buttomed cell culture dishes (Costar, Cambridge, MA, USA) with a pore diameter of $0.4 \mu$. Initially cells were used on days three to 35 to study the number of cells and the protein concentration. Having confirmed that the cell monolayers attained stable electrical resistance by the 20 th day, cells were studied on the 20th day after seeding, or later, for subsequent experiments.

\section{TRANSEPITHELIAL ELECTRICAL PARAMETERS OF CELL MONOLAYERS}

Transepithelial electrical parameters were measured as initially described for rabbit ileum by Schultz and Zalusky ${ }^{14}$ and later applied to cell culture. ${ }^{11}$ The filter was mounted in a modified Ussing chamber between two $15 \mathrm{ml}$ compartments, the mucosal and serosal compartments. The temperature of each compartment was thermostatically controlled at $37^{\circ} \mathrm{C}$, and the solution was continuously circulated and gassed with $95 \% \mathrm{O}_{2}-5 \% \mathrm{CO}_{2}$. The exposed surface area was $3.8 \mathrm{~cm} .{ }^{2}$ The transepithelial potential difference (PD) was measured with calomel electrodes in series with thin $3 \mathrm{M} \mathrm{KCl}$ agar bridges. Current pulses were passed through $\mathrm{Ag}-\mathrm{AgCl}$ electrodes in series with thin $\mathrm{KCl}$ bridges. The filter was short-circuited by an automatic voltage clamp (WPI, New Haven, CT, USA) that compensated for the resistance of the fluid and the filter itself. Current pulses were sent to measure the resistance of the filter according to Ohm's law. The offset of the electrodes was regularly checked by short-circuiting them with thin $3 \mathrm{M} \mathrm{KCl}$ bridges and disconnecting them from the Ussing chamber. The Ringer solution used consisted (in $\mathrm{mM}$ ) of $140 \mathrm{Na}^{+}, 5 \cdot 2 \mathrm{~K}^{+}, 120 \mathrm{Cl}^{-}, 25 \mathrm{HCO}_{3}^{-}, 1 \cdot 2$ $\mathrm{Ca}^{2+}, 2 \cdot 4 \mathrm{HPO}_{4}^{2-}, 0.4 \mathrm{H}_{2} \mathrm{PO}_{4}$, and $1 \cdot 2 \mathrm{Mg}^{2+}, \mathrm{pH}$ $7 \cdot 4$ with $5 \% \mathrm{CO}_{2}$. Amphotericin $\mathrm{B}$, amiloride, phlorizin, dibutyryl adenosine 3',5'-cyclic monophosphate (DbcAMP), histamine, 12-O-tetradecanoyl phorbol-13-acetate (TPA), serotonin creatinine sulphate, and cholera toxin were obtained from Sigma Chemical (St Louis, MO, USA). Diphenylamine-2-carboxylate (N-Pheny- lantranilic acid) (DPC) was obtained from Fluka (Mulhouse, France).

\section{MEASUREMENT OF CAMP AFTER ADDITION OF} CHOLERA TOXIN

Filter-grown cells were mounted in identical Ussing chambers used for transepithelial electrical measurements. In control experiments, monolayers were left in the chamber with Ringer solution for 10,45 , or 90 minutes, after which they were processed for cAMP measurement. In a second set of experiments, $5 \mu \mathrm{g} / \mathrm{ml}$ of cholera toxin was added to the mucosal solution and cells were assayed for cAMP and PKC after 10, 45 or 90 minutes. In a third set of experiments, $10^{-5} \mathrm{M}$ forskolin was added to the serosal solution and filters were assayed for cAMP after 20 minutes. The cells were deproteinised by ice cold $1 \mathrm{M}$ $\mathrm{HClO}_{4}$. After centrifugation at $2500 \mathrm{~g}$ for 15 minutes, the supernatant was removed and neutralised with $\mathrm{KOH}$. The cAMP present in the supernatant was removed, acetylated, ${ }^{15}$ and assayed by commercially available radioimmunoassay kits (cAMP RIA Pasteur Kit, Paris). Protein was determined by the method of Lowry $e t a l$, with BSA as standard. ${ }^{16}$

\section{MEASUREMENT OF cAMP AFTER ADDITION OF} DBCAMP

To evaluate the relation between the intracellular cAMP content and the induction of chloride secretion, cell monolayers were treated with different concentrations of DbcAMP $\left(10^{-5}\right.$, $5 \times 10^{-5}, 10^{-4}$, and $10^{-3} \mathrm{M}$ ) added to the serosal side. The short circuit current (Isc) was recorded constantly. Cells were assayed for cAMP content after 10 minutes of stimulation by DbcAMP. For $10^{-3} \mathrm{M}$ DbcAMP, two sets of experiments were done. In one group of experiments cells were assayed for cAMP when the stimulated Isc plateaued. In the second group, cAMP was assayed just at the onset of the stimulation of Isc.

\section{PKC ACTIVITY ASSAY}

The activity of PKC in cl 19A cells was measured after treatment of the cell monolayers with cholera toxin $(5 \mu \mathrm{g} / \mathrm{ml}$, mucosal) for 10,45 , and 90 minutes, or by TPA $(10 \mathrm{ng} / \mathrm{ml}$, mucosal $)$ for 10 minutes in an Ussing chamber. Cells from untreated monolayers served as controls. Cells were scraped from the Transwell culture dishes with $2 \mathrm{ml}$ ice cold buffer $(\mathrm{NaCl} 0 \cdot 15 \mathrm{M}$ and Tris$\mathrm{HCl} 20 \mathrm{mM}$, pH 7.5). All subsequent experiments were done at $4^{\circ} \mathrm{C}$. The cell suspensions were then centrifuged at $1000 \mathrm{~g}$ for five minutes. The supernatant was discarded and $2 \mathrm{ml}$ of homogenisation buffer A (Tris- $\mathrm{HCl} 20 \mathrm{mM}$, EGTA $0.5 \mathrm{mM}$, EDTA $2 \mathrm{mM}$, leupeptine $0 \cdot 1$ $\mathrm{mg} / \mathrm{ml}$, and phenyl methyl suphonyl fluoride 1 $\mathrm{mM}$ ) were added to each pellet of cells. The cells were then ruptured by 30 strokes in a Dounce homogeniser and centrifuged at $100000 \mathrm{~g}$ for one hour. The supernatant represented the cytosolic' fraction of PKC. The membrane pellet was resuspended in $2 \mathrm{ml}$ of buffer A containing 1\% Nornide P-40 by stirring for 10 minutes. The solubilised pellet was then centrifuged at 
TABLE I Stimulation of short circuit current (Isc) in cl 19A cell monolayers by various compounds (Values, mean (SEM))

\begin{tabular}{lllllll}
\hline Agent & $\begin{array}{l}\text { Final } \\
\text { concentration }\end{array}$ & $\begin{array}{l}\text { Added } \\
\text { to }\end{array}$ & $\begin{array}{l}\Delta P D \\
(m V)\end{array}$ & $\begin{array}{l}R \\
\left(\Omega . \mathrm{cm}^{-2}\right)\end{array}$ & $\begin{array}{l}\Delta I s c \\
\left(\mu A . \mathrm{cm}^{-2}\right)\end{array}$ & $\begin{array}{r}\text { No of } \\
\text { filters }\end{array}$ \\
\hline None & & & $0 \cdot 4(0 \cdot 03)$ & $201(6)$ & $2 \cdot 4(0 \cdot 2)$ & 88 \\
DbcAMP & $10^{-3} \mathrm{M}$ & $\mathrm{M}$ & $8 \cdot 8(0 \cdot 9)$ & $174(8)$ & $61(4 \cdot 5)$ & 11 \\
Epi & $10^{-5} \mathrm{M}$ & $\mathrm{S}$ & $6 \cdot 2(1 \cdot 4)$ & $146(23)$ & $42(7)$ & 5 \\
$\mathrm{Car}$ & $10^{-4} \mathrm{M}$ & $\mathrm{S}$ & $1 \cdot 3(0 \cdot 1)$ & $189(19)$ & $12(2)$ & 5 \\
His & $10^{-4} \mathrm{M}$ & $\mathrm{S}$ & $1 \cdot 4(0 \cdot 7)$ & $211(60)$ & $8(2)$ & 4 \\
A23187 & $2 \mu \mathrm{g} / \mathrm{ml}$ & $\mathrm{M}+\mathrm{S}$ & $2 \cdot 2(0 \cdot 9)$ & $158(3)$ & $20(5)$ & 4 \\
AmpB & $5 \mu \mathrm{g} / \mathrm{ml}$ & $\mathrm{M}$ & $8 \cdot 4(0 \cdot 3)$ & $174(25)$ & $35(10)$ & 4 \\
$\mathrm{CT}$ & $5 \mu \mathrm{ug} / \mathrm{ml}$ & $\mathrm{M}$ & $6 \cdot 3(0 \cdot 6)$ & $195(14)$ & $37(5)$ & 7 \\
Fsk & $10^{-5} \mathrm{M}$ & $\mathrm{S}$ & $7 \cdot 8(0 \cdot 9)$ & $163(8)$ & $43(3)$ & 5 \\
\hline
\end{tabular}

Stimulation was reversed by adding $5 \times 10^{-5} \mathrm{M}$ bumetanide and $10^{-5} \mathrm{M}$ ouabain to the serosal side;

the addition of $10^{-3} \mathrm{M}$ barium chloride after bumetanide reduced the Isc. $S=$ serosal; $M=$ mucosal; $\Delta$ Isc, increase in Isc; $R$, electrical resistance of the filters before addition of the agents. $R$ did not vary significantly after the addition of different agents. $\triangle P D$, increase in potential difference; DbcAMP, dibutyryl 3', 5'-cyclic AMP; CT, cholera toxin; Fsk, forskolin; AmpB, amphotericin B; Epi, epinephrine; His, histamine; Car, carbachol.

Figure 1: Effect of different substances on short circuit current (Isc) of cl 19A cell monolayers. Dibutyryl adenosine 3', 5'-cyclic monophosphate (DbcAMP) (10 $10^{-3} \mathrm{M}$ serosal); epinephrine $\left(10^{-5} \mathrm{M}\right.$ serosal); calcium ionophore A23187 $(2 \mu \mathrm{g} / \mathrm{ml}$ mucosal+serosal) amphotericin $B(5 \mu g / m l$ mucosal), and carbachol mucosal), and carbachol $\left(10^{-4} \mathrm{M}\right.$ serosal); $\mathrm{BaCl}_{2}$, barium chloride $\left(\mathrm{BaCl}_{2}\right)$ $\left(10^{-3} \mathrm{M}\right.$ serosal); ouabain (Oua) $\left(10^{-4} \mathrm{M}\right.$ serosal).
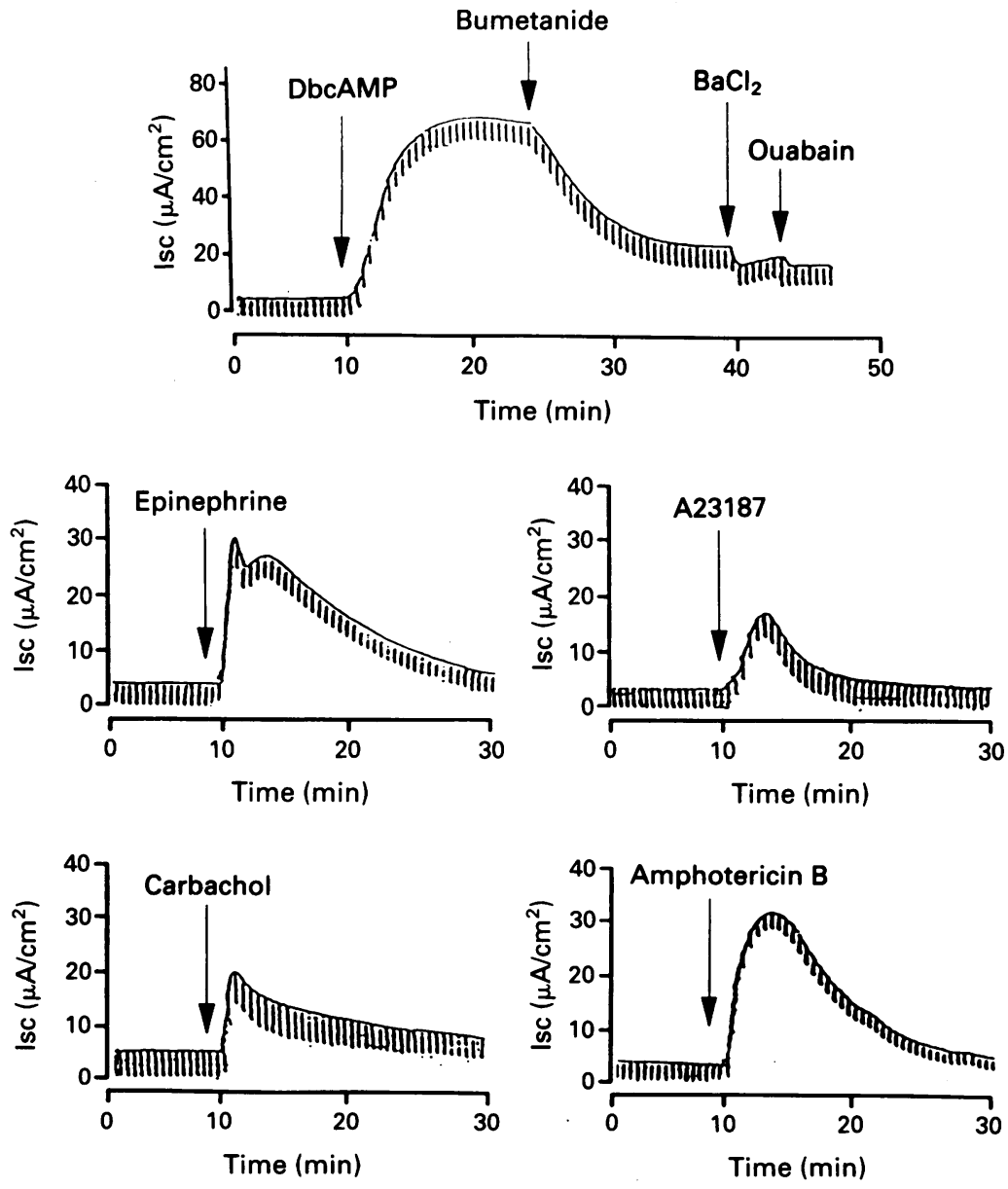

STATISTICAL ANALYSIIS

Data were analysed by using the SAS package (SAS Institute Inc). ${ }^{19}$ Analysis of variance was undertaken to compare the means among the different groups of filters.

\section{Results}

STANDARDISATION OF HT-20 CL 19A CELL MONOLAYERS

\section{Seeding density}

Cells were seeded at different concentrations $\left(10^{5}\right.$ to $2 \times 10^{6}$ cells $\left./ \mathrm{cm}^{2}\right)$ and their numbers and protein content were measured from the 10th day in culture. The number of cells and the protein concentration increased with the age of culture except at the seeding density of $2 \times 10^{6}$ cells $/ \mathrm{cm}^{2}$ or above, when the cells did not grow well.

The maximum number of cells and the protein content were obtained with a seeding density of $10^{6} \mathrm{cells} / \mathrm{cm}^{2}$. Eventually seeding was done at this concentration for all the filters used in the experiments.

\section{Basal electrical parameters}

The mean (SEM) transepithelial electrical PD $(0.4(0.03) \mathrm{mV}, \mathrm{n}=88)$ and Isc $(2.4(0.2)$ $\left.\mu \mathrm{A} . \mathrm{cm}^{-2}, \mathrm{n}=88\right)$ values were small but significantly different from zero. The electrical polarity (serosa positive) was consistently observed. When compared with the basal electrical parameters of cl 19A cells cultured on HAHY Millipore filters, however $(\mathrm{PD}=0.33(0.03) \mathrm{mV}$,

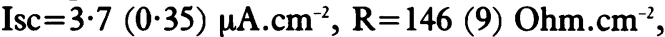
$n=15$ ), the electrical resistance of the monolayers on Transwell dishes (201 (6) Ohm. $\mathrm{cm}^{-2}, \mathrm{n}=88$ ) was significantly higher $(p<0.0004)$ and the Isc significantly lower $(p<0.0001)$, while the PD did not vary significantly.

\section{Effects of various compounds on electrogenic chloride secretion}

The effects of various compounds on the Isc of the filter grown cells are shown in Table I. Typical Isc recordings after addition of the different substances are represented in Figure 1. Serosal addition of $10^{-3} \mathrm{M}$ DbcAMP, $10^{-5} \mathrm{M}$ epinephrine, $10^{-4} \mathrm{M}$ carbachol, and $10^{-4} \mathrm{M}$ histamine raised the Isc. The rise in the Isc was also observed after the addition of $2 \mathrm{ng} / \mathrm{ml}$ calcium ionophore A 23187 , added to both the mucosal and serosal sides. The stimulation of Isc was inhibited by $10^{-4} \mathrm{M}$ bumetanide or $10^{-4} \mathrm{M}$ ouabain added to the serosal side. Serosal addition of $10^{-3} \mathrm{M} \mathrm{BaCl}_{2}$ after bumetanide reduced the Isc further. Mucosal addition of $5 \mathrm{ng} / \mathrm{ml}$ amphotericin B also enhanced the Isc. Serosal addition of serotonine $\left(10^{-7} \mathrm{M}\right.$ to $\left.10^{-2} \mathrm{M}\right)$ had no effect on the Isc. Substitution of chloride by sulphate or isethionate in the bathing solution resulted in the absence of or minimal Isc stimulation (results not shown) by these agents. Pretreatment of the cells with DPC, an agent known to inhibit chloride conductance in the apical membrane of cultured colonic cells and intestinal 
tissues abolished almost totally the increase in Isc induced by these agents. These results strongly suggest that these agents induce electrogenic chloride secretion in cl 19A cell monolayers. Monolayers on Transwell dishes responded in a similar fashion to monolayers obtained on HAHY Millipore filters as judged by their response to DbcAMP. The magnitude of the increase in Isc induced by DbcAMP in Millipore filters (Isc $\left.=61(4 \cdot 5) \mu \mathrm{A} . \mathrm{cm}^{-2}, \mathrm{n}=11\right)$ was not significantly different from the increase obtained in Transwell filters $\left(\mathrm{Isc}=69 \cdot 2(7) \mu \mathrm{A} \cdot \mathrm{cm}^{-2}, \mathrm{n}=15\right.$, $\mathrm{p}<0 \cdot 18)$. The increase in Isc after serosal addition of $10^{-3} \mathrm{M}$ DbcAMP was immediate and the maximum stimulation of Isc was attained in about four minutes in both the monolayers and Isc remained stable thereafter.

Addition of mucosal or both mucosal and serosal $10^{-2} \mathrm{M}$ glucose, $0.5 \mathrm{mM}$ mucosal phlorizin after glucose, and $10^{-5} \mathrm{M}$ mucosal amiloride had no effect on the Isc.

\section{EFFECT OF CHOLERA TOXIN ON ELECTRICAL}

PARAMETERS AND INTRACELLULAR CAMP

A typical recording of the change in Isc of cl 19A cell monolayers after the mucosal addition of cholera toxin $(5 \mu \mathrm{g} / \mathrm{ml})$ is given in Figure 2. In nine filters, the Isc did not change until about 22 minutes after the addition of cholera toxin. The Isc then increased gradually to reach its maximum in about 90 minutes, and remained stable thereafter. The electrical resistance of the cell monolayers was not changed significantly by the addition of cholera toxin.

The effects of cholera toxin on electrical parameters and the cellular cAMP content 10 , 45 , and 90 minutes after its addition are represented in Table II. Ten minutes after the addition of cholera toxin, there was no significant change in the Isc or the intracellular cAMP content. At 45 minutes, both the Isc and cAMP increased significantly and continued to increase till 90 minutes.

Figure 2: Typical recording of short circuit current (Isc) of $\mathrm{cl} 19 \mathrm{~A}$ cell monolayers after the mucosal addition of cholera toxin $(5 \mu \mathrm{g} / \mathrm{ml})$.

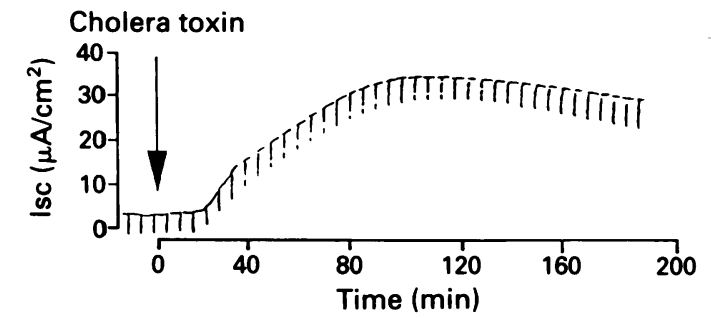

TABLE II Effects of cholera toxin and forskolin on electrical parameters and intracellular messengers in cl 19A cells. (Values, mean (SEM))

\begin{tabular}{|c|c|c|c|c|c|c|c|}
\hline Agent & $\begin{array}{l}\text { Time } \\
(\text { min })\end{array}$ & $\begin{array}{l}I s c \\
\left(\mu A \cdot \mathrm{cm}^{-2}\right) l\end{array}$ & $\begin{array}{l}P D \\
(m V)\end{array}$ & $\begin{array}{l}R \\
\left(\Omega . \mathrm{cm}^{-2}\right)\end{array}$ & $\begin{array}{l}c A M P \\
\text { (pmol/mg } \\
\text { protein) }\end{array}$ & $\begin{array}{l}\text { Protein } \\
\text { (mg/filter) }\end{array}$ & $\begin{array}{l}\text { No of } \\
\text { filters }\end{array}$ \\
\hline $\begin{array}{l}\text { None } \\
\text { Cholera } \\
\text { Toxin } \\
\text { Forskolin }\end{array}$ & $\begin{array}{r}0 \\
10 \\
45 \\
90 \\
20\end{array}$ & $\begin{array}{c}1 \cdot 7(0 \cdot 6) \\
1 \cdot 9(0 \cdot 3) \\
22 \cdot 2(5 \cdot 7) \dagger \\
35 \cdot 2(5 \cdot 2) \ddagger \\
36 \cdot 4(3 \cdot 3)\end{array}$ & $\begin{array}{l}0.27(0.11) \\
0.3(0.04) \\
4 \cdot 1(0.96) \dagger \\
6.5(1.02) \ddagger \\
6.8(0.75)^{\star}\end{array}$ & $\begin{array}{l}174(16) \\
186(8) \\
194(36) \\
196(18) \\
173(5)\end{array}$ & $\begin{array}{c}2 \cdot 6(0 \cdot 6) \\
3 \cdot 2(0 \cdot 2) \\
10 \cdot 1(1 \cdot 7) \dagger \\
99 \cdot 2(23 \cdot 8) \ddagger \\
106 \cdot 8(28 \cdot 8)^{\star}\end{array}$ & $\begin{array}{l}3 \cdot 1(0 \cdot 2) \\
3.0(0 \cdot 1) \\
2.9(0 \cdot 1) \\
2 \cdot 8(0 \cdot 1) \\
3.5(0 \cdot 1)\end{array}$ & $\begin{array}{l}9 \\
4 \\
4 \\
4 \\
4\end{array}$ \\
\hline
\end{tabular}

Isc = short circuit current $P D=$ potential difference $R=$ resistance; $c A M P=$ cyclin adenosine monophosphate.

Time 0 corresponds to the measurements under basal conditions (Ringer).

$\star$ Significantly different from time $0(p<0.05)$.

tSignificantly different from time 0 and $10(p<0.05)$

$\ddagger$ Significantly different from time 9,10 , and $45(p<0.05)$

\section{Effect of cholera toxin on PKC activity}

PKC activity in cl 19A cells was not significantly affected by the action of cholera toxin for 10,45 , or 90 minutes (Fig 3). The mean (SEM) activities of the particulate and cytosolic fractions of PKC were 192 (25) and 661 (55) pmol. $\mathrm{min}^{-1}$.mg protein $^{-1}$ respectively under control conditions. The values of these factions after 10,45 or 90 minutes of cholera toxin treatment were $209(51)$ and 820 (23); 202 (43) and 573 (26); 224 (15) and 605 (33) pmol. $\mathrm{min}^{-1} . \mathrm{mg}$ protein ${ }^{-1}$ respectively, and were not significantly different from control conditions or between the different time periods. However, stimulation of cl 19A cells by TPA (a well known activator of PKC) for 10 minutes resulted in a significant increase in the particulate fraction of PKC (36.04 (2.4)\% v 22.84 (2.67)\%; $\mathrm{p}<0.03$ ) with a simultaneous decrease in the cytosolic fraction $(65 \cdot 36 \quad(2 \cdot 71) \% \quad v \quad 77 \cdot 16$ $(2.67) \% ; \mathrm{p}<0.009)$. The activation of PKC by TPA was accompanied by an increase in Isc $(2 \cdot 15$ $\left.(1 \cdot 4) v 39 \cdot 3(6 \cdot 2) \mu \mathrm{A} . \mathrm{cm}^{-2}\right)$.

\section{EFFECT OF FORSKOLIN ON ELECTRICAL}

\section{PARAMETERS AND CAMP}

To determine whether another agent that induces chloride secretion primarily by increasing the cAMP level through direct activation of the catalytic subumit of adenylate cyclase, the effect of forskolin was also studied in cl 19A cells. Twenty minutes after the serosal addition of $10^{-5} \mathrm{M}$ forskolin the cellular cAMP content increased significantly $(2 \cdot 58(0 \cdot 59) v 106 \cdot 8(28 \cdot 8)$ $\mathrm{pmol} / \mathrm{mg}$ protein). The increase in cAMP by

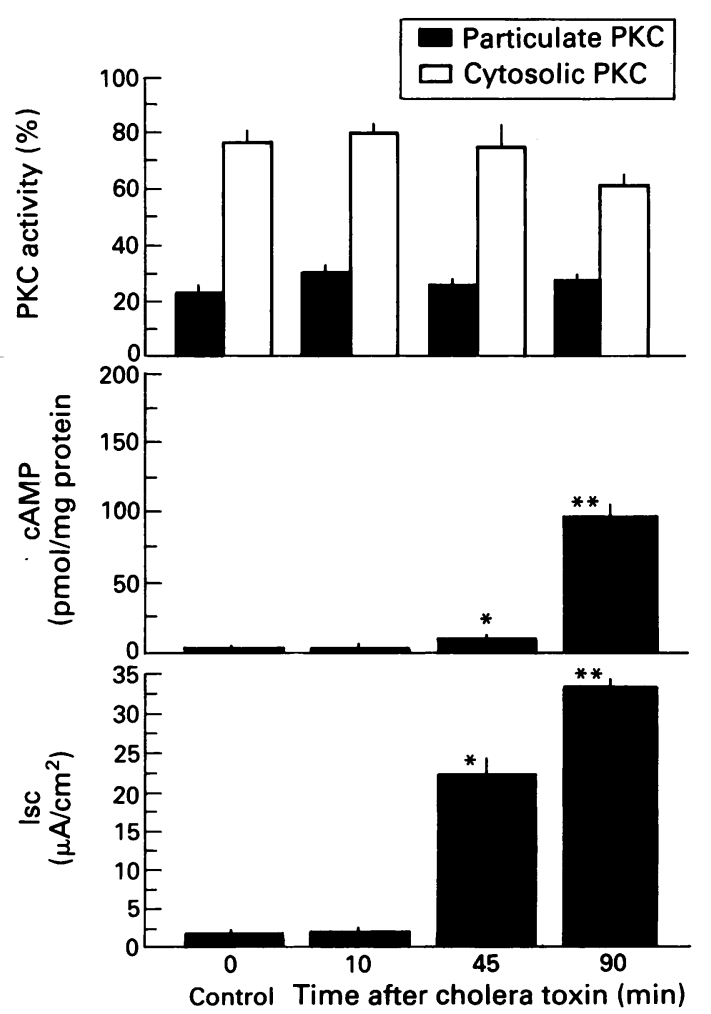

Figure 3: The time course of changes in the short circuit current (Isc), cyclic adenosine monophosphate (cAMP), and protein kinase $C(P K C)$ after the addition of cholera toxin $(C T)$ in cl $19 A$ cells.

$\star$ Significantly different from control or time 10 minutes; $\star \star$ significantly different from time 45 minutes. 
Figure 4: Effect of different concentrations of dibutyryl adenosine 3',5'-cyclic on the short circuit current (Isc) of cl 19A cell monolayers. The lower of represents the experiments when $C A M P$ was measured at the onset of the increase in Isc while the upper one represents the maximal Isc stimulation. monophosphate (DbcAMP) the two traces for $10^{3} \mathrm{M}$
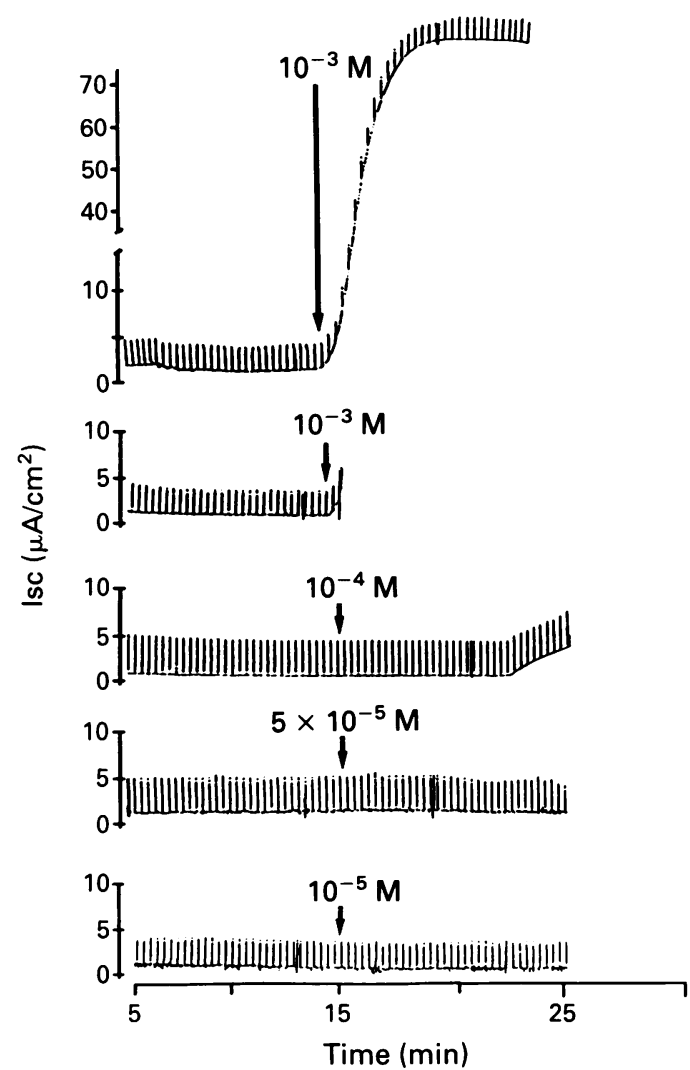

forskolin was accompanied by maximum stimulation of Isc without significant modification of the electrical resistance of the monolayers (Table II).

The effect of different concentrations of DbcAMP on the Isc is represented in Figure 4. The smallest concentration of DbcAMP that stimulated the Isc $\left(\Delta 4.5 \mu \mathrm{A} / \mathrm{cm}^{2}\right)$ was $10^{-4} 5 \mathrm{M}$ added to the serosal side and the corresponding increase in intracellular cAMP content was $\Delta \mathbf{6 . 7}$ $\mathrm{pmol} / \mathrm{mg}$ protein (Table III). The onset of Isc stimulation occurred about eight minutes after the addition of DbcAMP $\left(10^{-4} \mathrm{M}\right)$.

An immediate increase in Isc was caused by the addition of $10^{-3} \mathrm{M}$ DbcAMP to the serosal side; this stimulated Isc plateaued in four minutes and remained stable thereafter. The intracellular concentration of CAMP just at the onset of the increase in Isc was $28.7(6.3) \mathrm{pmol} / \mathrm{mg}$ protein, and at maximal Isc stimulation $(69 \cdot 2)(5 \cdot 3)$ $\left.\mu \mathrm{A} . \mathrm{cm}^{-2}\right)$ it was $178 \cdot 9(35 \cdot 7) \mathrm{pmol} / \mathrm{mg}$ protein).

Discussion

Our results confirm that cholera toxin enhances

TABLE III Rise in intracellular cyclic adenosine monophosphate (cAMP) concentration $(\Delta$ $c A M P)$ and short circuit current $(\Delta I s c)$ induced by different agents

\begin{tabular}{lcllcc}
\hline Agent & Concentration & Added to & $\begin{array}{l}\text { Time } \\
(\text { min })\end{array}$ & $\begin{array}{l}\Delta I s c \\
\left(\mu A . \mathrm{cm}^{2}\right)\end{array}$ & $\begin{array}{c}\Delta c A M P \\
(\text { pmol/mg } \\
\text { protein })\end{array}$ \\
\hline Cholera & $5 \mu \mathrm{g} / \mathrm{ml}$ & Mucosal & 10 & $0 \cdot 2$ & $0 \cdot 66$ \\
Toxin & $5 \mu \mathrm{g} / \mathrm{ml}$ & Mucosal & 45 & $21 \cdot 7$ & $7 \cdot 3$ \\
DbcAMP: & $5 \mu \mathrm{g} / \mathrm{ml}$ & Mucosal & 90 & $33 \cdot 2$ & $97 \cdot 3$ \\
& $10^{-5}$ & Serosal & 10 & 0 & 0 \\
& $5 \times 10^{-5} \mathrm{M}$ & Serosal & 10 & 0 & 0 \\
& $10^{-4} \mathrm{M}$ & Serosal & 10 & $4 \cdot 5$ & $6 \cdot 7$ \\
& $10^{-3} \mathrm{M}$ & Serosal & onset $\uparrow$ Isc & $11 \cdot 3$ & $26 \cdot 7$ \\
Forskolin & $10^{\times 3} \mathrm{M}$ & Serosal & 10 & $67 \cdot 5$ & $176 \cdot 3$ \\
\hline
\end{tabular}

Delta values are difference of means from at least four experiments for each agent and each concentration or time period. DbcAMP, dibutyryl 3',5'-cAMP. the Isc and increases intracellular cAMP. In addition, they indicate that in a cloned cell line, cholera toxin-stimulated chloride secretion is concomitant with an increased cAMP value and is not related to PKC activity. These events take place in the secretory cell monolayer.

When interpreting the results obtained in intestinal cells in culture, it is important to define the system used. We, therefore, characterised the epithelial functional properties of the clone $19 \mathrm{~A}$ of the human colon carcinoma cell line HT-29 grown on Transwell porous-bottomed dishes which provide independent access to both sides of a cell monolayer. The cl 19A cells form a uniform, electrically resistant monolayer on this support without collagen. The cell monolayers obtained were electrically polarised and they responded to DbcAMP, forskolin, calcium ionophore A23187, amphotericin B, epinephrine, histamine, and cholera toxin by an increase in Isc that was inhibited by bumetanide and ouabain. This suggested that cl 19A cells mount a chloride secretory response when stimulated by these agents. The effects of DbcAMP and VIP in this cell line grown on a different support (Millipore filters) has already been reported earlier. ${ }^{20}$ Recently, VIP receptors have also been characterised in these cells. ${ }^{21}$ In this respect, the functional properties of the cl $19 \mathrm{~A}$ cell monolayers obtained on Transwell porous-bottomed dishes without collagen were not different from those cultivated on Millipore filters. In cl 19A cells different types of chloride channels have been reported to be regulated by forskolin and carbachol. ${ }^{22}$

Under basal conditions, cl 19A cells did not display absorptive properties. The Isc was not affected by the addition of amiloride and glucose which suggested lack of amiloride-sensitive $\mathrm{Na}$ conductance and sodium coupled glucose absorption in these cells. In total, cl 19A cell monolayers displayed the characteristic features of secretory epithelium, the primary target of cholera toxin.

One advantage of using cells in culture is that, within certain limits, they remain identical through the several weeks of experiments. Cells are cultured in the same medium on the same supports under standardised conditions to obtain monolayers with comparable basal electrical parameters. Cultivating the cells on porousbottomed dishes, as in the present study, provides access to both the mucosal and the serosal surfaces of the cell monolayers when the cells are being cultured. Thus, transepithelial electrical parameters can be measured directly under sterile conditions. Monolayers with comparable basal electrical parameters can then be utilised to study the transepithelial transport processes. It is evident from Tables I and II that the electrical resistance and protein content of the cell monolayers were fairly comparable. Electrical resistance of the monolayers obtained on Transwell dishes was higher in comparison to the monolayers on Millipore filters which suggest that the monolayers on Transwell dishes are well connected by tight junctions.

The cl 19A cells were sensitive to cholera toxin. Another cell line, HRT-18 ${ }^{10}$ has also been reported to be sensitive to cholera toxin. The lag 
period of Isc stimulation by cholera toxin in $\mathrm{cl}$ $19 \mathrm{~A}$ cells was of the same order as that reported for the HRT-18 cells but both maximum Isc stimulation and the time taken to attain it were higher in the cl 19A than in HRT-18 cells. The delay in the Isc stimulation is longer in the rabbit ileum. The increase in Isc induced by cholera toxin coincided with that in cAMP, which increased in parallel with the enhanced Isc. This suggests that the stimulation of Isc, which reflects transepithelial chloride secretion induced by the cholera toxin, is mediated principally through increased intracellular cAMP.

This study compared the levels of intracellular cAMP and the corresponding electrogenic chloride secretion as reflected by the increased Isc. Two types of agent were evaluated: cholera toxin and forskolin. Both of these act by increasing intracellular cAMP through activation of adenylate cyclase. Forskolin directly activates the catalytic subunits of adenylate cyclase whereas cholera toxin activates the subunits of the enzyme in an indirect manner through the GTP binding protein $G_{s}$. The nature of Isc stimulation by these two agents is also different: forskolin causes an immediate rise in the Isc whereas the cholera toxin induced Isc rise is accompanied by a lag period. Because DbcAMP induces chloride secretion in cl 19A cells, these were treated with different concentrations of DbcAMP to determine the minimal increase in intracellular cAMP that is coupled with chloride secretion. The threshhold value of the increase in intracellular cAMP that induces electrogenic chloride secretion is around $7 \mathrm{pmol} / \mathrm{mg}$ protein. Interestingly, however, with similar increase in cAMP the rise in Isc induced by cholera toxin was significantly higher than that associated with DbcAMP. The reason for this remains to be evaluated further. Compared with DbcAMP, both cholera toxin and forskolin stimulated the Isc to the similar extent for comparable rise in intracellular cAMP. Maximally stimulated Isc by DbcAMP, cholera toxin, and forskolin was proportionate to the rise in intracellular cAMP.

This study also examined the effect of cholera toxin on PKC activity. To our knowledge this is the first report of the action of cholera toxin on PKC activity. PKC has been shown to be implicated in the regulation of electrolyte transport in different organs including the intestine. In certain cell types PKC either inhibits or potentiates cAMP production..$^{23}$ In T-84 cells, activation of PKC attenuates prostaglandin $\mathrm{E}_{2}$ responses. ${ }^{24} \mathrm{~T}-84$ cells are capable of electrogenic chloride secretion when stimulated by cAMP, calcium inophore, VIP, and carbachol. ${ }^{25-27}$ PKC has also been shown to be implicated in the chloride secretory process by the tracheal epithelium $^{28}$ and by the intestine. ${ }^{29}$

The model of secretory cell monolayers can be important in identifying the various biochemical events related to transport abnormalities that accompany the severe diarrhoea in cholera, especially those events that take place in the epithelial cells.

S K Nath was supported by a scholarship from the Ministere des Affaires Etrangers, Direction Generale des Relations Culturelles.

Presented at the 92nd Annual Meeting of the American

Presented at the 92nd Annual Meeting of the American
Gastroenterological Association and published in abstract form Gastroenterological Association and
(Gastroenterology 1991; 100: A698).
1 Fasano A, Baudry B, Pumplin DW, Wasserman SS, Tall BD, Ketley JM, et al. Vibrio cholerae produces a second enterotoxin, which affects intestinal tight junctions. Proc Natl Acad Sci USA 1991; 88: 5242-6.

2 Field M, Fromm D, Al-awquati Q, Greenough III WB. Effect of cholera toxin on ion transport across isolated ilea mucosa. f Clin Invest 1972; 51: 796-804.

3 Kimberg DV, Field M, Jhonson J, Henderson A, Gershon E. Stimulation of intestinal mucosal adenylate cyclase by Stimulation of intestinal mucosal adenylate cyclase by
cholera enterotoxin and prostaglandins. $\mathcal{F}$ Clin Invest 1971 : 50: 1218-30.

4 Sharp GWG, Fischer J, Lipson LG, Kholer TR, Flores J Witkum PN. Time course studies on the mechanism of action of cholera toxin. In: Bonfils $S$, Fromageot $P$, Rosselin $\mathrm{G}$, eds. Hormonal Receptors in Digestive Tract Physiology. Amsterdam: Elsevier, 1977; 447-54

5 Beubler E, Horina G. 5-HT, and 5-HT, receptor subtypes mediate cholera toxin-induced intestinal fluid secretion in the rat. Gastroenterology 1990; 99: 83-9.

6 Beubler E, Kollar G, Saria A, Bukhave K, Rask-madsen J. Involvement of 5-hydroxytryptamine, prostaglandin $\mathrm{E}_{\text {, }}$ and cyclic adenosine monophosphate in cholera toxin induced fluid secretion in the small intestine of rat in vivo. Gastroenterology 1989; 96: 368-76.

7 Cassuto J, Jodal $M$, Tuttle $R$, Lundgren $O$. On the role of intramural nerves in the pathogenesis of cholera toxininduced intestinal secretion. Scand f Gastroentrol 1981; 16: induced in 84.

8 Peterson JW, Ochoa LG. Role of prostaglandins and cAMP in the secretory effects of cholera toxin. Science 1989; 245: 857-9.

9 Ben mansour A, Rautureau M, Tome D, Bisalli A, Desjeux JF. In vitro effects of tetrodotoxin and hexamethonium on electrolyte transport in rabbit ileum treated with cholera toxin (Abstract). Gastroenterology 1988; 94(5): A32.

10 Nath SK, Rautureau M, Heyman M, Reggio H, L'helgoualc'h A, Desjeux JF. Emergence of Na +-glucose cotransport in an epithelial secretory cell line sensitive to cholera toxin. Am F Physiol 1989; 256: G335-41.

11 Grasset E, Gernabeu J, Pinto M. Epithelial properties of human colonic carcinoma cell line Caco-2: effect of human colonic carcinoma cell line Caco-2:

12 Augeron C, Laboisse CL. Emergence of permanently differentiated cell clones in a human colonic cancer cell line in culture after treatment with sodium butyrate. Cancer Res $1984 ; 44$ 3691-9.

13 Chen TR. In situ detection of mycoplasma contamination in cell cultures by fluorescent Hoechst 33258 stain. Exp Cell Res 1977; 104: 255-62.

14 Schultz SG, Zalusky R. Ion transport in isolated rabbit ileum I. Short circuit current and 1 Ja fluxes. $\mathcal{F}$ Gen Physiol 1964 47: 567-84.

15 Fraudsen EK, Krishna G. A simple ultrasensitive method for the assay of cyclic AMP and cyclic GMP in tissues. Life Sci 1977; 18: 529-42.

16 Lowry OH, Rosenbrough NJ, Randall RJ. Protein measurement with the folin reagent. F Biol Chem 1953; 193: 265-75.

17 Fan X, Huang X, Da silva C, Castagna $M$. Arachidonic acid and related methyl ester mediate protein kinase $C$ activation in intact platelet through the arachidonate metabolism pathways. intact platelet through the arachidonate metabolism path
Biochim Biophysiol Res Commun 1990; 169(3): 933-40.

18 Bradford $M$. A rapid and sensitive method for the quantitation of microgram quantities of protein utilizing the principle of protein dye binding. Anal Biochem 1976; 72: 248-54.

19 SAS Institute Inc (1985). SAS user's guide: statistics. Version 5 Edition, Cary, North Carolina: SAS Institute Inc.

20 Augeron C, Maoret JJ, Laboisse CL, Grasset E. Permanently differentiated cell clones isolated from the human colonic adenocarcinoma cell line HT-29: possible models for the study of ion transport and mucus production. In: Alvarado $\mathrm{F}$, Van Os $\mathrm{CH}$, eds. Ion-gradient coupled transport. Amsterdam: Elsevier, 1986: 363-6.

21 Rouyer-fessard C, Augeron C, Grasset E, Maert JJ, Laboisse $\mathrm{CL}$, Laburthe M. VIP receptors and control of short circuit current in the human intestinal clonal cell line $\mathrm{Cl} 19 \mathrm{~A}$. Experientia $1989 ; 45: 1102-5$.

22 Vaandrager AB, Bajnath R, Groot JA, Bot AG, De Jonge HR. $\mathrm{Ca}^{2+}$ and cAMP ativate different chloride efflux pathways in HT-29 cl.19A clonic epithelial cell line. Am $\mathcal{F}$ P hysiol 1991; 261: G958-65.

23 Nishizuka Y. Studies and perspectives of protein kinase C. Science 1986; 233: 305-12.

24 Warhurst G, Higgs NB, Lees $M$, Tonge A, Turnberg LA Activation of protein kinase $\mathrm{C}$ attenuates prostaglandin $\mathrm{E}$ responses in a colonic cell line. Am $\mathcal{F}$ Physiol 1988; 255: G27-32.

25 Cartwright CA, Mcroberts JA, Mandel KG, Dharmsathaphorn $\mathrm{K}$. Synergestic action of cyclic AMP and calcium mediated chloride secretion in a colonic epithelial cell line. $\mathcal{F}$ Clin Invest 1985; 76: 1837-42.

26 Dharmsathaphorn K, Mandel KG, Massui H, Mcroberts JA VIP-induced chloride secretion by a colonic epithelial cell line: direct participation of a basolaterally localized line: direct participation of a basolaterally localized
$\mathrm{Na}^{\prime}, \mathrm{K}, \mathrm{Cl}$ cotransport system. F Clin Invest 1985; 75: $462-71$.

27 Dharmsathaphorn K, Pandol S. Mechanism of chloride secretion induced by carbachol in a colonic epithelial cell line. f Clin Invest 1986; 77: 348-54.

28 Li M, McCann JD, Anderson MP, Clancy JP, Liedtke CM Nairn AC, et al. Regulation of chloride channels by protein kinase $\mathrm{C}$ in normal and cystic fibrosis airway epithelia. Science 1989; 244: 1353-6.

29 Fondacaro JD, Henderson LS. Evidence for protein kinase C as a regulator of intestinal transport. Am $\mathcal{F}$ Physiol $1985 ; 249$. G422-6. 